\title{
Collagenous matrix as a predictor for bone formation: a digital technique for collagen quantification
}

\section{Matriz colagenosa como preditor de formação óssea: uma técnica digital para quantificação de colágeno}

Gerson Arisoly Acasigua*

Henrique Müller de Quevedo*

Anna Christina Medeiros Fossati***

\section{Resumo}

The collagenous matrix plays a fundamental role in the process of bone regeneration, so it is essential to study how it is primarily formed in situations in which critical bone defects are created. Objective: this study seeks to quantify the collagenous matrix formed in critical bone defects in the calvaria of mice over the process of bone regeneration promoted by the association of poly(lactide-co-glycolide) (PLGA) porous scaffolds and stem cells from deciduous teeth (SCDT). In addition, this study attempted to establish a precise protocol for the digital quantification of collagen through a histological method. Materials and method: Nine Wistar rats were used, in which critical defects of $8.0 \mathrm{~mm}$ of diameter were made in their calvarium. The animals were divided into three groups $(n=9)$ : I - PLGA scaffolds; II - PLGA scaffolds/SCDT; III - PLGA scaffolds/SCDT maintained in osteogenic medium for 13 days. Within sixty postoperative days, calvaria were removed for histometric analysis following a digital protocol. A specific digital analysis method was designed for this study, in which a more precise quantification and differentiation between collagen fibers and non-collagenous tissue was possible, excluding factors that would normally alter the results. Results: it was noted that the association of PLGA scaffolds and SCDT maintained in osteogenic medium resulted in collagen matrix formation statistically higher than the other groups $(p<0.05)$. Conclusion: the protocol designed for collagen quantification was precise and efficient, producing methodologically standardized results.

Keywords: Bone regeneration. Collagen. Stem cells. Histological techniques.

\section{Introduction}

Bone formation occurs in two distinct phases: endochondral ossification, in which the connective cartilage tissue is replaced with bone; and intramembranous ossification, in which bones are shaped directly from condensations of mesenchymal cells without a cartilage intermediate. In both processes, the cell responsible for bone matrix formation is the osteoblast, which will synthesize collagenous and non-collagenous proteins required for bone formation. The bone matrix synthetized by the osteoblast is composed by collagen fibers arranged in different orientations, which form the immature bone. In a second process, this matrix is replaced with a compact bone of well-arranged and organized collagen fibers, which form the mature bone ${ }^{1,2}$.

Every time an injury is inflicted on the bone structure, the organism immediately tries to regenerate the damaged tissue through inflammatory response $^{3}$. This regeneration occurs naturally in most cases of small bone fractures, but when a critical bone defect is created, this process becomes more complex and regeneration is negatively affected $^{4}$. In these cases, tissue-engineering strategies may be used to assist organic processes with the use of three-dimensional scaffolds often associated with cells with osteogenic potential to induce tissue repairs-7.

Using a computer software is essential for objectively evaluating histological tissues. To effectively quantify and compare the composition of different

\footnotetext{
Dentistry Post-graduation Programme, Federal University of Rio Grande do Sul.

Dentistry Post-graduation Programme, University of São Paulo.

* Dentistry Post-graduation Programme, Department of Morphological Sciences; Federal University of Rio Grande do Sul, Brazil.
} 
tissues, a strict protocol of slide staining, photographic capture, and digital analysis must be followed to ensure a reliable quantification method ${ }^{8}$.

Considering that the presence of a collagenous matrix precedes the final stage of bone formation ${ }^{9}$, this study aimed to analyze the collagenous fiber formation in a situation of bone regeneration and to establish a precise and efficient quantification protocol for detecting collagenous tissue through a histological and computerized method.

\section{Materials and method}

\section{Nanofiber Scaffolds}

Nanofiber scaffolds (Figure 1) were prepared according to a previously published method ${ }^{10}$. A poly- meric solution of poly(D,L-acid lactic- co-glycolic acid) (75:25) (PLGA) (Sigma Aldrich, St Louis, MO, USA) was dissolved in 1,1,1,3,3,3-hexafluoro-2-propanol (Sigma Aldrich) until the final concentration of the solution reached $12 \%(\mathrm{w} / \mathrm{v})$, and it was maintained in a magnetic stirrer for 24 hours. The solution was placed in a 1-mL syringe equipped with a $21 \mathrm{G}$ metallic needle $(0.8 \mathrm{~mm}$ of internal diameter $)$ and subjected to the electrospinning process for 3 hours. For this process, a voltage difference of $12 \mathrm{kV}$ and a flow rate of $0.24 \mathrm{~mL} / \mathrm{h}$ were used. The scaffolds were formed on 15-mm diameter glass coverslips placed on aluminum collecting plates and fixed at a distance of $15 \mathrm{~cm}$ from the needle. All the experiments were performed at room temperature $\left(\sim 25^{\circ} \mathrm{C}\right)$ and relative air humidity of around $35 \%$. After the preparation of the scaffolds, they were sterilized with ultraviolet light for 1 hour.
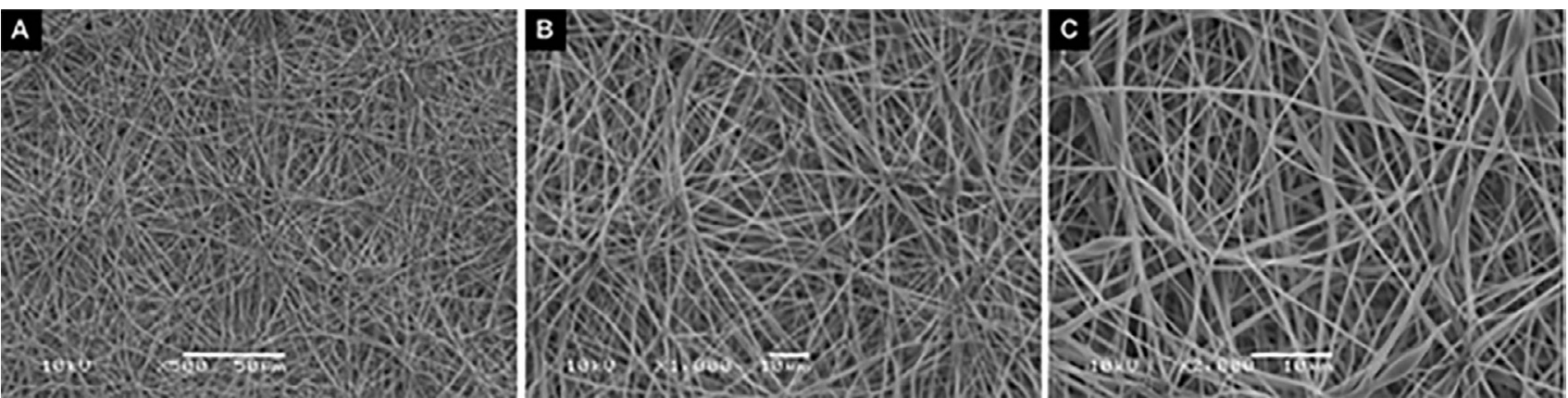

Figure 1 - Microscopic structure of nanofiber scaffolds with scanning electron microscopy (SEM) at 500x (a), 1000x (b), 2000x (c).

\section{Cell Cultivation and Seeding}

A deciduous tooth in resorption process was extracted and immersed in $1 \mathrm{~mL}$ of DMEM/Hepes (Dulbecco's Modified Eagle Medium/4-(2-hydroxyethyl)-1-piperazineethanesulfonic acid, Sigma-Aldrich), 10\% fetal bovine serum (Laborclin, Pinhais, Brazil), $100 \mathrm{U} / \mathrm{mL}$ penicillin, $100 \mu \mathrm{g} / \mathrm{mL}$ streptomycin (Gibco, Grand Island, NY), and 0.45 $\mu \mathrm{g} / \mathrm{mL}$ gentamicin (Gibco). The person responsible for the patient signed a consent form approved by the ethics committee. The pulp tissue of the tooth was removed and handled according to the protocol previously described to isolate stem cells from deciduous teeth (SCDT) ${ }^{11}$. After the digestion process, the resulting cell suspension was seeded into a 12 -well plate and the culture medium was changed every 3 days. When the culture reached $90 \%$ confluence, the cells were detached with $0.5 \%$ trypsin-EDTA (Sigma-Aldrich) and passage was performed. In the $5^{\text {th }}$ passage (P5), $5 \times 10^{4}$ viable cells concentrated in $1 \mathrm{~mL}$ of DMEM were seeded into the sterilized scaffolds, and incubated at $37^{\circ} \mathrm{C}$ with $5 \% \mathrm{CO}_{2}$ humidity. Following this procedure, in vivo implants were performed.

\section{Cell Phenotype and Pluripotency}

The pluripotency capacity evaluation of SCDT was performed according to the procedure reported by Bernardi and colleagues ${ }^{11}$ (2011). The cells were then maintained in an induction medium for 2 weeks after reaching $70 \%$ confluence. Three specific media were used: (1) adipogenic - Iscove (Gibco), $20 \%$ human plasma, $10^{-7} \mathrm{~mol} / \mathrm{L}$ dexamethasone, 2.5 $\mathrm{mg} / \mathrm{mL}$ bovine insulin, $5 \mathrm{mmol} / \mathrm{L}$ indomethacin, 5 $\mathrm{mmol} / \mathrm{L}$ rosiglitazone, and $10 \mathrm{IU} / \mathrm{mL}$ of sodium heparin; (2) chondrogenic - DMEM/HEPES, $50 \mathrm{nmol} / \mathrm{L}$ ascorbic acid 2-phosphate, $6.25 \mathrm{mg} / \mathrm{mL}$ bovine insulin, and $10 \mathrm{ng} / \mathrm{mL}$ transforming growth factor-beta 1 (TGF-b1) (Millipore, Tokyo, Japan); and (3) osteogenic - DMEM/HEPES, $10 \%$ fetal bovine serum; $10 \%$ b-glycerophosphate $(10 \mathrm{mmol} / \mathrm{L})$, ascorbic acid 2-phosphate $(5 \mathrm{mg} / \mathrm{mL})$ and $0.1 \%$ dexamethasone $\left(10^{-5} \mathrm{~mol} / \mathrm{L}\right)$. Cells were then fixed in $4 \%$ paraformaldehyde and stained to reveal differentiation with Alizarin red, Oil Red, or Alcian blue. The experiments were performed in triplicate and SCDT were maintained in a conventional culture medium as negative control.

For evaluating the stem cell immune profile, $10^{6}$ cells were incubated with conjugated antibodies for 
30 minutes at $4^{\circ} \mathrm{C}$ with CD29/PE, CD34/PE, CD44/ FITC, CD45/FITC, CD90/FITC, CD117/PE, and HLA-DR/FITC (PharMingen-BD Biosciences, San Diego, CA, USA), CD133/PE (Milteny Biotech, Auburn, CA, USA), and CD146/FITC and Stromal Cell Surface Marker 1 (STRO-1)/FITC (Santa Cruz, Santa Cruz, CA, USA). To identify viable cells, $1 \mathrm{mg} / \mathrm{mL}$ of 7-amino actinomycin D (7AAD, Invitrogen, Carlsbad, CA, USA) was used. Data were analyzed using the CellQuest software (BD Biosciences).

\section{Osteogenic Differentiation}

After 24 hours of initial cell seeding into the scaffolds, the DMEM was removed and an osteogenic medium (DMEM/Hepes, 10\% fetal bovine serum, $10 \%$ b-glycerophosphate, $10 \mathrm{mM}, 1 \%$ ascorbic acid 2 -phosphate $5 \mathrm{mg} / \mathrm{mL}$, and $0.1 \%$ dexamethasone $10^{-}$ ${ }^{5} \mathrm{M}$ ) was added over a period of 13 days; the medium was changed every 3 days. After 13 days, the cells were fixed in $4 \%$ paraformaldehyde and $4 \%$ sucrose in PBS and then stained with $2 \%$ Alizarin Red in Milli-Q water.

\section{Animal Surgery and Scaffold Implantation}

Nine male Wistar rats (300-350g) were acquired from the animal reproduction and experimentation center laboratory of the Federal University of Rio Grande do Sul (UFRGS), Brazil. The animals were anesthetized and a bone critical defect (Figure 2) was made in the calvarium of each animal with a trephine drill $(8 \mathrm{~mm})$. Each animal was then allocated to one of the following experimental groups (three animals per group): I - implant of scaffolds without cells; II - implant of scaffolds seeded with SCDT; III - implant of scaffolds seeded with SCDT previously maintained in osteogenic medium for 13 days. For groups I and II, the scaffolds (with or without cells) were maintained in DMEM medium for 14 days before implantation. For group III, 24 hours after the cells were seeded into the scaffolds, the DMEM was changed for the osteogenic medium. After 13 days, the scaffolds with cells were implanted. For all groups, in the 14 days prior to implantation, the scaffolds were maintained incubated at $37^{\circ} \mathrm{C}$ with $5 \% \mathrm{CO}_{2}$ humidity and the medium was changed every 3 days. The scaffolds for animal implantation were detached from glass coverslips where they had formed before implantation. During the 14 days of culturing, the scaffolds shrunk, which led to a diameter reduction, from $15 \mathrm{~mm}$ to $8 \mathrm{~mm}$, thus filling the bone defect completely. Three stacked scaffolds were implanted in each bone defect. At 60 days after implantation, rats were euthanized and their calvarium removed for analysis. This study was approved by the Ethics Committee for Animal Use (protocol number 19273) of the Federal University of Rio Grande do Sul (UFRGS), Brazil.

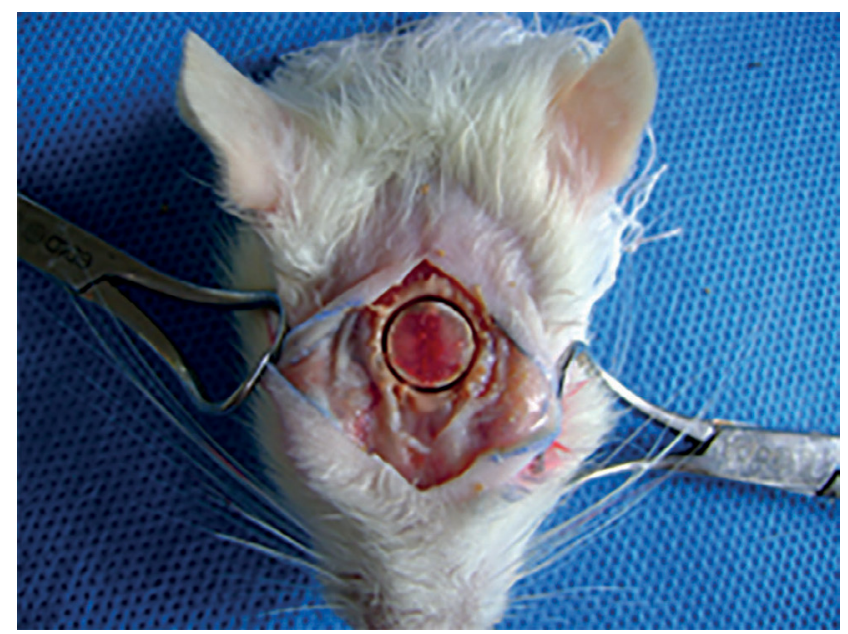

Figure 2 - A critical bone defect was made in the calvarium of each animal with a trephine drill $(8 \mathrm{~mm})$.

\section{Histological and Digital Evaluation}

A specific protocol was adopted for this study to provide a precise method for the digital quantification of collagen fibers through a histological technique. The technical procedure followed a strict protocol to guarantee that all histological paraffin blocks were sliced with the same width $(4 \mu \mathrm{m})$, all slides were stained at the same moment and staining battery, all slide pictures were taken at the same magnification (40x) and light intensity, and all pictures were saved in the same format and pixel resolution $96 \mathrm{dpi}$. These 4 protocol steps are essential to ensure a precise digital quantification of collagen fibers ${ }^{12}$ and will be further explained.

Each calvarium was fixed, decalcified, and embedded in paraffin. Histological sections of $4 \mu \mathrm{m}$ were obtained and stained with Mallory's trichrome technique for detecting collagen fibers. Two slides of each sample were randomly chosen and their mean was measured. In addition, all slides were stained at the same moment and staining battery. Each section was analyzed with an optical microscope and their areas were captured at 40x magnification with a binocular microscope (Olympus Optical Co. CX41RF), along with a video camera (Olympus ${ }^{\mathrm{TM}}-$ Qcolor 5, Coolet, RTV) and a computer (Dell ${ }^{\mathrm{TM}}$ - Dimension 5150) with the Qcapture ${ }^{\mathrm{TM}}$ software (v.2.81). Each image obtained was saved in ".tiff" format with 96 $\mathrm{dpi}$, considering that ImageJ. 1.46r software quantifies collagen tissue by the pixels presented in the image. The images obtained were merged to reconstruct the defect area of each sample (Figure 3). The software Photofiltre 6.5.3 was used to avoid change of contrast, brightness, and saturation, allowing a correct merge of the different images of the same sample. The area analyzed was determined horizontally by the edges of the bone defect originally created, and vertically by the epithelial tissue above the bone defect area and the neural tissue below it. To exclude blank areas among tissues, technical defects (tissue tearing areas), and lumen of vessels, 
the "pipette" and "replace color" tools of the Photofiltre software were used. All blank areas were colored in green allowing excluding all non-tissue pixels (Figure 4). Using the "color deconvolution" plugin of the ImageJ $1.46 \mathrm{r}$ software, collagen fibers were isolated in blue color. The maximum threshold of 254 was used to determine the total amount of collagen pixels in the image and the "analyze particles" tool quantified the number of pixels. Compact collagen was measured with an intermediate threshold of 200 , thus excluding lighter fibers, and their pixels were quantified by the "analyze particles" tool (Figure 5).

\section{Group 1. Scaffolds}

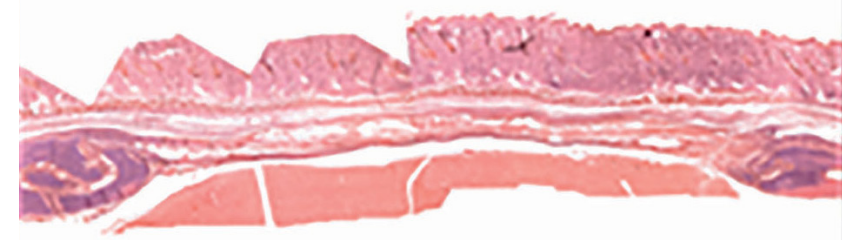

\section{Group 2. Scaffolds + SCDT}

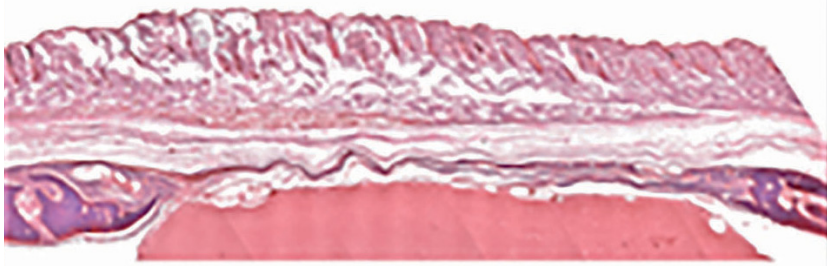

Group 3. Scaffolds + SCDT in ostoogenic modium

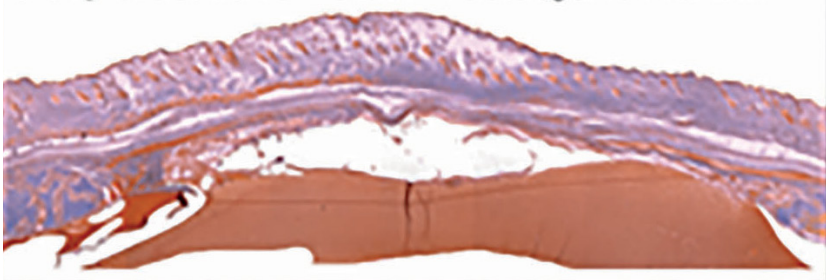

Figure 3 - Samples of histological sections from groups I, II, and III. Visual color differences can be seen among groups

\section{A}
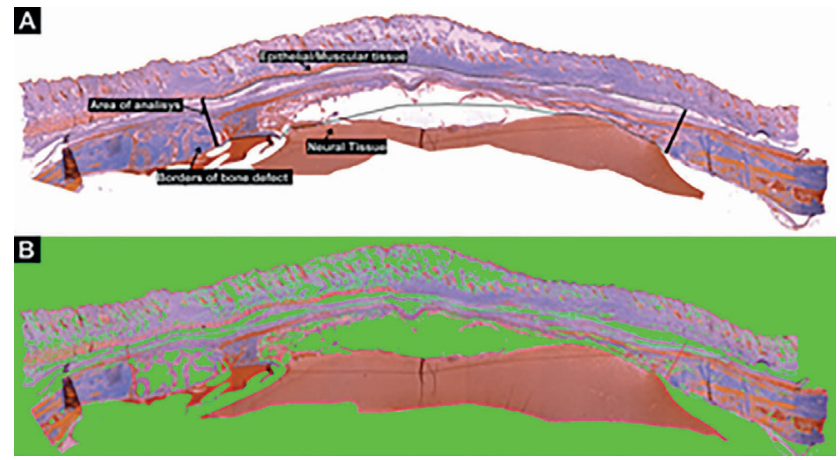

Figure 4- A: Analysis area limited by the black line in the center of the figure surrounded by the adjacent structures. B: Exclusion of non-tissue areas marked in green color

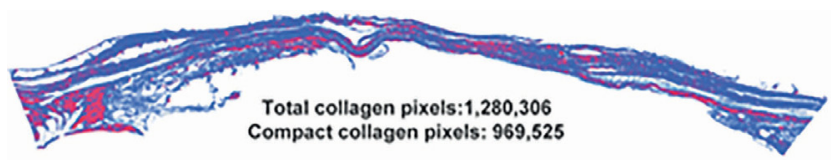

Figure 5 - Isolated total collagen fibers in blue color and compact collagen fibers in red color, quantified by the Image J. 1.46 r software, using maximum threshold (254) and intermediate threshold (200), respectively

The analysis of non-collagenous tissue pixels required a previous preparation of the image. All non-tissue areas were colored the same as collagen tissue, forcing the Image J. software to recognize collagen and non-tissue pixels as the same, thus isolating the non-collagenous tissue. The image was then inverted and non-collagenous pixels were quantified by the "analyze particles" tool (Figure 6).

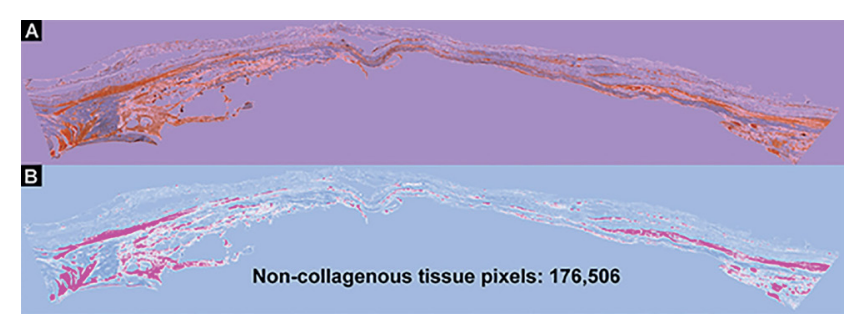

Figure 6-A: Non-tissue areas colored the same as collagen fibers. $B$ : Isolated and quantified non-collagenous tissue

The amount of pixels of collagenous and non-collagenous tissues was added to define the entire tissue inside the bone defect and each percentage was calculated. The amount of compact collagen was defined as a percentage of the total amount of collagen. Data obtained in this study were crossed with the previous bone formation data from the study by Acasigua ${ }^{10}$ (2014).

\section{Statistical Analysis}

Data are presented as mean \pm SD (standard deviation) and indicated as statistically significant by analysis of variance (ANOVA), using Tukey's test as post test for multiple comparisons. All data were analyzed using the GraphPad software (San Diego, CA, USA). Differences among means were considered significant when $\mathrm{p}<0.05$.

\section{Results}

Table 1 - Descriptive statistical analysis

\begin{tabular}{l|l|r|r|r}
\cline { 3 - 4 } \multicolumn{2}{c}{} & $\mathrm{n}$ & Average \% & \multicolumn{1}{c}{$\sigma$} \\
\hline \multirow{4}{*}{ Total Collagen } & Group 2a & 3 & 20,6 & 3,6 \\
& Group 1b & 3 & 49,9 & 10,7 \\
& Group 3c & 3 & 88,0 & 4,9 \\
\hline & Total & 9 & 52,8 & 29,9 \\
\hline \multirow{4}{*}{ Compacted Collagen } & Group 2a & 3 & 6,8 & 5,7 \\
& Group 1a & 3 & 30,6 & 18,1 \\
& Group 3b & 3 & 72,2 & 18,3 \\
\hline & Total & 9 & 36,5 & 31,5 \\
\hline
\end{tabular}


Surgical procedures and the implantation of different materials caused no clinical changes in the animals and there were no signs of infection or any change in the wounded area. The histomorphometric analysis showed that the rate of total collagen formation was $49.9 \pm 10.7 \%, 20.6 \pm 3.6 \%$, and 88.0 $\pm 4.9 \%$ in groups I, II, and III, respectively (Table 1). Total collagen formation was different among groups $(\mathrm{p}<0.01)$ with higher formation in group III when compared with the other groups. The rate of compact collagen formation was $30.6 \pm 18.1 \%, 6.8$ $\pm 5.7 \%$, and $72.2 \pm 18.3 \%$ in groups I, II, and III, respectively. More compact collagen was present in group III when compared with the other groups $(p<0.005)$ and there was no difference between groups I and II (Table 1).

\section{Discussion}

Several studies have evaluated bone regeneration by only measuring osteogenic neoformation ${ }^{13-16}$. However, collagen fibers play a fundamental role in the formation of bone organic matrix. Even so, we are not aware of studies evaluating the relationship between the presence of collagenous tissue and bone formation by digital and histological methods.

In this study, the expression of collagen fibers was compared with the findings on bone formation of a previously published paper ${ }^{10}$, which found that the association of scaffolds and osteogenic stimulated stem cells promoted higher bone formation than the control group. The same pattern was observed in our data, in which the group of stimulated stem cells showed more total collagen formation than the other groups. Considering that a collagen framework is required for bone formation, its analysis may be used as a predictor for future bone regeneration.

Interestingly, group 1, which only used scaffold to fill the critical defect, showed more $(\mathrm{p}<0.05)$ collagen fibers than group 2 (scaffold + undifferentiated stem cells). A possible explanation to this observation is that due to the local inflammatory process there was a delay in the differentiation of stem cells into osteoblasts and a consequent decrease in collagen formation. On the other hand, the scaffold itself worked as a framework for the cell environment assisting the healing process, as described by Bottaro ${ }^{17}$ (2002), Liunyun ${ }^{18}$ (2009), and Badylak $^{19}$ (2011).

The evaluation of collagen matrix performed by this study was a complementary analysis of a previous one ${ }^{10}$. This study found a significant amount of bone neoformation in bone defects of mice, which had been implanted with stem cells previously differentiated into an osteogenic medium and a PLGA scaffold. Yoon and colleagues used stem cells from fat tissue to test bone regeneration on critical de- fects in mice and found higher bone neoformation on groups implanted with stem cells previously differentiated into an osteogenic medium ${ }^{13}$. Even though these two studies did not evaluate the formation of collagen matrix, the bone formation results also followed the same pattern found in our study, due to methodological similarity. In 2009, Murphy, Haugh, and O'Brien ${ }^{20}$ used collagenous scaffolds originally created for regenerative skin grafts and combined them with osteoblasts, evaluating cellular adhesion to collagen scaffolds with different porosities ( $96 \mu \mathrm{m}$ and $151 \mu \mathrm{m}$ ). The authors concluded that collagen scaffolds with lower porosities had better adhesion with osteoblasts, stressing the need for a nanofiber scaffold and showing the importance of the collagen matrix to bone formation.

The most common method for evaluating collagen tissue is through the ImageJ (1.46r) computer software. It analyzes collagen percentage in a previously established area inside a slide picture captured by an optical microscope. This software has a color deconvolution plugin that identifies pixels containing collagen fibers colored in blue stain. However, this method has a few limitations, considering it only quantifies the percentage of collagen fibers in a given area, not including interstitial spaces, lumen of vessels, and defects and blank spots that are common in the histological technique, which gives a sometimes distorted rate of collagen tissue during the analysis.

Although several studies ${ }^{8,21,22}$ also analyzed the spatial distribution of collagen fibers, they did not specifically quantify the amount of collagen fibers in relation to non-collagenous tissue, but only the percentage of collagen pixels on a given picture area. Due to tissue characteristics in our study, adapting the analysis technique and creating a specific methodology was required. The combination of Photofiltre and ImageJ software allowed us to evaluate the percentage of collagen pixels in relation to non-collagenous tissue, regardless of the area size chosen for analysis. This modification provided a more precise quantification of both collagenous and non-collagenous tissues, excluding factors that could alter data, such as interstitial spaces, the interior of vessels, and technique defects. This computerized analysis, along with a specific protocol for including specimens, slicing blocks, staining, and capturing pictures, ensured a more reliable method for collagen tissue quantification.

Data analysis showed that using scaffolds coupled with stem cells differentiated into an osteogenic medium promoted a higher production of collagen fibers that will serve as a matrix for bone regeneration. The results of collagen production agree with the bone regeneration findings of a previous study by Acasigua and colleagues ${ }^{10}(2014)$. 


\section{Conclusion}

The computerized protocol created for the quantification of collagen fibers provides a standardized method for evaluating the collagenous and non-collagenous matrix. Techniques for a more precise collagen evaluation are scarcely found in the literature and our protocol may be adapted for analyzing other tissues.

\section{Resumo}

A matriz colagenosa tem um papel fundamental no processo de regeneração óssea, por isso é essencial estudar como ela é formada principalmente em situações nas quais defeitos ósseos críticos são criados. Objetivo: o presente trabalho busca quantificar a matriz colagenosa formada em defeitos ósseos críticos na calvária de ratos, durante o processo de regeneração óssea promovido pela associação de scaffolds de ácido poli (láctico-co-glicólico) (PLGA) e células-tronco de dentes decíduos (SCDT). Além disso, procurou-se estabelecer um protocolo preciso para a quantificação digital de colágeno por meio de um método histológico. Materiais e método: Foram utilizados nove ratos Wistar, nos quais foram produzidos defeitos críticos de $8,0 \mathrm{~mm}$ de diâmetro na calvária. Os animais foram divididos em três grupos $(n=$ 9): I - scaffolds de PLGA; II - scaffolds de PLGA / SCDT; III - scaffolds de PLGA / SCDT mantidas durante 13 dias em meio osteogênico. Sessenta dias pós-operatório, as calvarias foram removidas para análise histométrica seguindo um protocolo digital. Um método de análise digital específico foi projetado para este estudo, no qual uma quantificação e diferenciação mais precisas entre fibras de colágeno e tecido não-colágeno foi possível, excluindo fatores que normalmente alterariam os resultados. Resultados: notou-se que a associação entre scaffolds de PLGA e SCDT mantidos em um meio osteogênico resultou em uma formação de matriz de colágeno estatisticamente maior que os outros grupos $(p<0,05)$. Conclusão: o protocolo projetado para a quantificação de colágeno foi preciso e eficiente, produzindo resultados metodologicamente padronizados.

Palavras-chave: Regeneração óssea. Colágeno. Células-tronco. Técnicas histológicas.

\section{References}

1. Velleman SG. The role of the extracellular matrix in skeletal development. Poultry science 2000 79(7):985-9.

2. Soltanoff CS, Yang S, Chen W, Li YP. Signaling networks that control the lineage commitment and differentiation of bone cells. Critical reviews in eukaryotic gene expression 2009 19(1):1-46.

3. Singer NG, Caplan AI. Mesenchymal stem cells: mechanisms of inflammation. Annual review of pathology 2011 6:457-78.

4. Lemperle SM, Calhoun CJ, Curran RW, Holmes RE. Bony healing of large cranial and mandibular defects protected from soft-tissue interposition: A comparative study of spontaneous bone regeneration, osteoconduction, and cancellous autografting in dogs. Plastic and reconstructive surgery 1998 101(3):660-72

5. Meng X, Leslie P, Zhang Y, Dong J. Stem cells in a three-dimensional scaffold environment. SpringerPlus 2014 3:80.

6. Brodie JC, Goldie E, Connel G, Merry J, Grant MH. Osteoblast interactions with calcium phosphate ceramics modified by coating with type I collagen. Journal of biomedical materials research Part A. 2005 73(4):409-21.

7. El-Amin SF, Lu HH, Khan Y, Burems J, Mitchell J, Tuan RS, et al. Extracellular matrix production by human osteoblasts cultured on biodegradable polymers applicable for tissue engineering. Biomaterials 2003 24(7):1213-21.

8. Miot HA, Brianezi G. Morphometric analysis of dermal collagen by color clusters segmentation. Anais brasileiros de dermatologia 2010 85(3):361-4.

9. Montes GS. Structural biology of the fibers of the collagenous and elastic systems. Cell biology international 1996 20(1):1527.

10. Xavier Acasigua GA, Bernardi L, Braghirolli DI, Filho MS, Pranke P, Medeiros Fossati AC. Nanofiber scaffolds support bone regeneration associated with pulp stem cells. Current stem cell research \& therapy 2014 9(4):330-7.

11. Bernardi L, Luisi SB, Fernandes R, Dalberto TP, Valentim L, Bogo Chies JA, et al. The isolation of stem cells from human deciduous teeth pulp is related to the physiological process of resorption. Journal of endodontics. 2011 37(7):973-9.

12. Niethammer M, Borland D, Marron JS, Woosley J, Thomas NE. Appearance Normalization of Histology Slides. Machine learning in medical imaging MLMI. 2010 6357:58-66.

13. Yoon E, Dhar S, Chun DE, Gharibjanian NA, Evans GR. In vivo osteogenic potential of human adipose-derived stem cells/poly lactide-co-glycolic acid constructs for bone regeneration in a rat critical-sized calvarial defect model. Tissue engineering 2007 13(3):619-27.

14. Jukes JM, Both SK, Leusink A, Sterk LM, van Blitterswijk CA, de Boer J. Endochondral bone tissue engineering using embryonic stem cells. Proceedings of the National Academy of Sciences of the United States of America. 2008 105(19):6840-5.

15. Chang SC, Wei FC, Chuang H, Chen YR, Chen JK, Lee KC, et al. Ex vivo gene therapy in autologous critical-size craniofacial bone regeneration. Plastic and reconstructive surgery 2003 112(7):1841-50.

16. Lucarelli E, Donati D, Cenacchi A, Fornasari PM. Bone reconstruction of large defects using bone marrow derived autologous stem cells. Transfusion and apheresis science : official journal of the World Apheresis Association : official journal of the European Society for Haemapheresis 2004 30(2):169-74

17. Bottaro DP, Liebmann-Vinson A, Heidaran MA. Molecular signaling in bioengineered tissue microenvironments. Annals of the New York Academy of Sciences 2002 961:143-53.

18. Liuyun J, Yubao L, Chengdong X. Preparation and biological properties of a novel composite scaffold of nano-hydroxyapatite/chitosan/carboxymethyl cellulose for bone tissue engineering. Journal of biomedical science 2009 16:65.

19. Badylak SF, Brown BN, Gilbert TW, Daly KA, Huber A, Turner NJ. Biologic scaffolds for constructive tissue remodeling. Biomaterials 2011 32(1):316-9.

20. Murphy CM, Haugh MG, O'Brien FJ. The effect of mean pore size on cell attachment, proliferation and migration in collagen-glycosaminoglycan scaffolds for bone tissue engineering. Biomaterials 2010 31(3):461-6. 
21. Meyer AL, Berger E, Monteiro Jr O, Alonso PA, Stavale JN, Goncalves MP. Quantitative and qualitative analysis of collagen types in the fascia transversalis of inguinal hernia patients. Arquivos de gastroenterologia 2007 44(3):230-4.

22. Schneider RK, Puellen A, Kramann R, Raupach K, Bornemann J, Knuechel R, et al. The osteogenic differentiation of adult bone marrow and perinatal umbilical mesenchymal stem cells and matrix remodelling in three-dimensional collagen scaffolds. Biomaterials 2010 31(3):467-80.ensional collagen scaffolds. Biomaterials 2010 31(3):467-80.

\section{Endereço para correspondência:}

Gerson Arisoly Acasigua

Ramiro Barcelos St. 2496

90035-003 Porto Alegre-RS

Fone: (51) 33085003

E-mail: gacasigua@yahoo.com.br

Recebido: 31/10/2016. Aceito: 19/02/2017. 